\title{
IMF AND ASIA: CHANGING TRENDS IN ENGAGEMENT (1997-2017)
}

\author{
Effulgence \\ Vol. 16 (Special Issue) \\ January - June, 2018 \\ Rukmini Devi Institute of Advanced Studies \\ E-mail : effulgence@rdias.ac.in, Website : www.rdias.ac.in \\ http://effulgence.rdias.ac.in/user/default.aspx \\ https://dx.doi.org/10.33601/effulgence.rdias/v16/iSpl1/2018/article0.11
}

S. Harikumar, Research Scholar, School of Humanities \& Social Sciences, Gautam Buddha University, Greater N oida, India, sharikumars@gmail.com

Dr. Rakesh Kumar Srivastava, Assistant Professor, School of Management, Gautam Buddha University, Greater Noida, India, rakesh@gbu.ac.in

Dr. Vivek M ishra, Assistant Professor, School of Humanities \& Social Science, Gautam Buddha University, Greater Noida, India, vivek@gbu.ac.in

\begin{abstract}
IMF engagement with Asia dates back to its formative years, however the focus had shifted more during the time of devastating 1997-98 Asian financial crisis. During the period the export oriented fast growing economies of viz: Indonesia, Thailand, South Korea etc caught in the quicksand of financial contagion had sought IM F assistance for rescue. IMF financial assistance had salvaged these beleaguered economies however the stringent conditionality had also invited wide criticism, Indonesia is case in point. After a decade (2007-2012), the financial crisis has hit the advanced economies which has again brought IMF to limelight and financial community had realised the relevance of the multilateral lender. During this time IMF has offered significant financial assistance to Eurozone economies, the assistance to Greece was highest of that sort. The conditionalities of the subject programme however has given rise to huge public discontent underscoring the fact that in spite of reviews in IM F conditionality there has been no substantial change in Fund's approach to politically and economically sensitive issues. Another important development in the last two decades is the emergence of Asian countries such as China and India as significant players in global trade. Asian economies relatively unhurt by the global financial crisis undertook significant role in stabilising global economy by associating with G-20 platform, IM F and other multilateral institutions. The establishment of New Development Bank (BRICS Bank) and Asian Infrastructure Investment Bank (AIIB) are other important developments from the region. Sensing the changing trends IMF also as part of its latest governance reforms has provided greater role for emerging economies by increasing their quotas. In fact the major change in the last twenty years is increasing economic relevance of emerging economies of Asia and their reaffirming role in IM F governance structure.
\end{abstract}

Key Words: IMF, Asian Crisis, IMF's Policy and Assistance

\section{INTRODUCTION}

\section{The Establishment of International Monetary F und (IMF)}

During the post Great Depression period, the economic concern for USA was imperial preferential trading system with trade blocks redirecting trade to their block countries with exchange controls and tariffs. The U nited Kingdom (UK) was concerned with growing unemployment and convertibility of their currency, Pound Sterling (f). The emerging global economic concerns after $2^{\text {nd }}$ world war led to the requirement of new Monetary System. The idea was initially evolved by two eminent Economists, John Mynard Keynes (Advisor to the British Treasury) and Harry Dexter White (Chief International Economist, U.S. Treasury Department) in 1941. Both the economists while, negotiating the post-war International Monetary System, had considered the economic interest of their respective countries with focus on improving the Balance of Payments (BOP) and contemplated on definite relationship with gold for individual currencies. The final B retton woods agreement had more tolerant exchange rate control and limited burden to creditors' countries. The final blue print resulted in the establishment of the International M onetary Fund (IM F) and $\mathrm{W}$ orld Bank. In that way the IM F along with W orld Bank known as Bretton Woods twins, were created in an international conference held in Bretton Woods, New Hampshire, USA in July 1944. The conference was attended by 730 participants from 45 countries. The objective of the conference was to create a global framework for economic development and co-operation among the countries. IM F officially came into existence on 27 December 1945 and the Articles of A greement $^{1}$ was signed by 29 member countries.

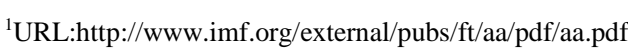




\section{Structure \& F unction of the IMF}

As per Charter, the mandate of IMF was to promote international monetary cooperation and provide policy and technical advice to the member states. The IMF financial assistance mainly directed to nations, who have Balance of Payment (BOP) problems, provides technical assistance to design policy programs for the countries affected by the crisis. The loan programmes of the IMF are funded by Quota ${ }^{2}$ contributions of the member countries. The loans are generally Short and M edium Term. The staff of the IM F are predominantly trained Economist with expertise in macroeconomics and finance.

The original aim of the establishment of IM F were to (1) promote International M onetary co-operation (2) facilitate the expansion and balanced growth of International Trade (3) Exchange Rate stability (4) support in establishing M ultilateral System of Payments (5) ensure the availability of resources to member states facing Balance of Payment problems. The IMF performs its mandated objectives by Surveillance, Lending and Capacity Building. Surveillance ${ }^{3}$ essentially involves the task of monitoring the economic and financial policies of the member countries. The IM F also publishes reports highlighting possible risk to economy and provides guidance with regard to domestic policy adjustments. IM F performs the role of a lender by providing financial support to countries facing actual/potential Balance of Payment problems. The support mainly aims at ensuring continuity in International Trade, Currency stability, building up Reserves and to restore and promote economic growth. The Capacity building ${ }^{4}$ role of the IMF is aimed at assisting the member states in designing policies that promote growth, stability and institutional capability(IM F, 2009).

The main source of finance for the IMF is Quotas by member states. Multilateral, bilateral borrowing and contribution based trust funds are other source of financial resource. Based on the relative size of the economy each country is assigned a quota in IM F. On

${ }^{2}$ Each member country of the IM F is assigned a Quota,based broadly on its relative position in the world economy.A member country's quota determines its maximum financial commitment to the IM $F$ its voting power, and has a bearing on its access to IM F financing. Retrieved URL:

http://www.imf.org/A bout/Factsheets/Sheets/2016/07/14/12/21/IM FQuotas?pdf $=1$

${ }^{3}$ Surveillance is conducted at domestic,regional and global levels to monitor potential risk factors

URL:http://www.imf.org/A bout/Factsheets/IM F-Surveillance?pdf =1 ${ }^{4} U R L$ : https://www.imf.org/en/A bout/Factsheets/imf-capacitydevelopment. joining the IMF, the country normally contributes 25 per cent of the quota in the form of widely accepted foreign currencies or through Special Drawing Rights ${ }^{5}$. The remaining part is paid through country's own currency. The revision of Quota takes place every five years.IMF also supplements their resources through multilateral borrowing. IMF also has $\mathrm{New}$ A rrangements to Borrow (NAB) wherein member countries and institutions can lend resources to the IM F $(I M F, 1997)$. The General Agreements to Borrow $(G A B)$ permits further borrowing from specific number of countries. According to IMF, NAB and GAB are second line of defence that provide enough capacity for the IM F to lend. Bilateral lending is another channel of resource for IM $\mathrm{F}$ lending. During the financial crisis in 2009-10, the Fund had resorted to this method and eventually the mechanism was incorporated in to NAB. However with crisis aggravating in Europe, this method was marshalled in as a third line of defence and is maintained under improved policy framework.

IM F also has in its asset base Gold holdings weighing 2814 metric tons and is one of the largest holders of Gold reserves. The Article of Agreement prohibits buying or engaging gold transaction by the institution. However with 85 per cent majority voting power, IM F can sell or accept Gold as payment by member countries. In 2010, as per Board approval IM F has sold 403 metric tons of Gold. The main objective of this sale on market price was to strengthen new income model of the Fund. The part of this income was used to subsidize financing to low income countries(IM F,2017a).

\section{SOUTH ASIAN CRISIS (1997)}

The South A sian economies have registered remarkable economic growth during the seventies and eighties. It was primarily driven by stellar export performance in the manufacturing sector particularly in electronics and semi-conductor industry. Malaysia was successful in establishing an export oriented food processing industry. Further these economies maintained currency stability through their currencies pegged to US Dollar (D owling, 1997). The conducive economic environment and macroeconomic stability has attracted both Foreign Direct Investment (FDI) and Portfolio Investment to these performing Asian economies. As per the World Bank and IMF data, the GDP growth rate of the period immediately preceding the crisis (1991-1995), stood at these levels-Indonesia $(7.8 \%)$, Korea $(7.50 \%)$, Malaysia (8.7\%), Philippines (2.2\%) and Thailand (8.5\%) (Garnaut and Ross, 2002:22).

${ }^{5}$ URL:https://www.imf.org/en/A bout/Factsheets/Sheets/2016/08/01/.../ Special-Drawing-Right-SDR 
According to the IMF, structural weaknesses of these economies were the fundamental reason for the crisis. The financial panic that followed exacerbated the crisis. There were no extensive macroeconomic issues preval ent these economies. However prior to crisis there has been widespread signs of vulnerabilities in these economies. There has been an elevated trend of short term funds being borrowed to finance long term project. The domestic banks piled up short term foreign debts which were channelized to domestic corporate for funding. Neither the domestic bank nor the corporate entity hedged their foreign currency exposure. This also triggered the crisis. Flow of investment to nonproductive real estate segment and niche industries was another visible vulnerability in the system (Corsetti,1998).A ccommodative Monetary Policy and perceived Exchange Rate stability due to currency peg had been main contributing factor for this rise in foreign currency denominated external debt (Claessens and A yhan,2013). Further, the flagging economic growth in Japan and Europe dried up the resources for domestic investment. The erratic movement Japenese $Y$ en/USD exchange rate were also the external factors that set the backdrop for the crisis (Stanley,1998).The news of possible interest rate hike in Japan during May 1997 ,though not taken place, has been the first trigger of crisis in the region with beginning of south Asian currency sell off. The crisis began on $2^{\text {nd }}$ July 1997 ,with Thailand announcing managed float after using USD 33 billion in foreign exchange( $N$ anto, 1998).

IM F authorities had sensed a possible foreign exchange crisis in Thailand in 1996 itself, when problem became visible in the market.IM $F$ had not made these warnings public to avoid precipitation of a crisis with this information. Thailand was extensively intervening in foreign exchange forward market thereby depleting the forex reserves .IM F was not aware of this development and against its expectation, the reserve became almost empty by the month of July 2017 and Thailand was forced to approach the Fund for emergency financial assistance.(A ghevli,1999).

Since 1995, Indonesia also experienced distressing developments in the financial market. The Government and the Central Bank has confronted these developments through very modest policy measures. Korea also has witnessed falling signs of economic fundamental during the time frame from 1995-1996. The widening of trade deficit and sluggish export performance along with falling profitability of debt ridden 'chaebols' were indications of the future trouble. Philippines, on the other hand were in more stable position with Government already under IMF programme has initiated privatization drive. The NonPerforming Assets(NPA) level of bank stood at a reasonable level of $3.4 \%$. However there has been considerable flow of funds to risky private sector projects and real estate sector. During J uly 1997, B aht, Rupiah and Peso had fallen by $25 \%, 9 \%$ and $10 \%$ respectively .The cumulative depreciation was to the extent of $30 \%$ in the next three months with led to attack on Korean Won in October 2017 and trend continued during the year. (Corsetti et al, 1998).

\section{IMF ROLE IN ASIAN FINANCIAL CRISIS}

The worst affected economies of South East Asian economies viz: Indonesia, Thailand and Korea resorted to IMF for assistance. The IM F financing was to the extent of US $\$ 40$ billion for these economies while another US $\$ 85$ billion was pooled from other lenders. Refer Table 1 for resources pledged to these economies as given.

Table 1: Commitment of International community in response to A sian C risis (US \$ Bn)

\begin{tabular}{|l|l|l|l|l|}
\hline Country & IM F & M ultilateral & Bilateral & Total \\
\hline Indonesia & 15 & 10 & 24.70 & 49.70 \\
\hline Korea & 21,10 & 14,2 & 23.10 & 58.40 \\
\hline Thailand & 4 & 2.70 & 10.50 & 17.20 \\
\hline Source: https://www.imf.org/external/np/exr/ib/2000/062300.htm \\
\hline
\end{tabular}

The Fund confronted the crisis through three ways viz: financing, macroeconomic policies and structural reforms. In the macroeconomic front, the Monetary Policy was tightened to stem the fall of exchange rate. The fiscal policy was also tightened in all these countries and various steps were initiated to bolster the governance aspect of financial and corporate sector. (Enoch, 2000).

\section{IMF Conditionality}

The adverse financial condition generally warrants a country to borrow from international community. When IM F lends, the borrowing government agrees to make appropriate change in economic policies to surmount the problems and these conditions ensure that the loan is repaid to the Fund. According to IM F, conditionality essentially include design of IM F programmes and tools employed to track the progress towards goals mutually agreed by borrowing country and the Fund.(IM F, 2017, p 2).IM F conditionality evolved over a period of time and until eighties it had mainly focussed on macroeconomic policies. However, the scope and gambit of structural conditions were increased with growing lending to low income transition economies.

The IMF conditionality was prevailing since 1957 in different forms, it was codified and came to effect on 2 
March 1979 .During the period it has undergone modifications with an extensive review which took place on 2002 and further in 2009 M arch.IM F B oard has reviewed conditionality guidelines again in 2012 bringing in Operational guidance primarily focussing on macro-social issues and improving surveillance. The 2014 IM F Review which had come into effect on J une 2015 has broadened policy outlook and included more flexible public debt rather than external debt criteria. .(IM F, 2017, p 2).

IM F financing approval and review is based on mainly four aspects viz: Prior actions, Quantitative Performance Criteria (QPC), Indicative Targets and Structural B enchmarks. Prior actions essentially refers to creating conducive policy background for successful implementation/continuation of the program.IM F has citied the removal of price control as an example for prior action by the borrower country.QPC is the most important gaugeable condition that has to be achieved for the Fund to complete the review process. According to IM F monetary and credit aggregates, forex reserve level, fiscal position and external debt level are some of the measurable conditionality set during the program implementation. Indicative targets which are measurable criteria are also put in place apart from QPCs. In case of certain specific situation in a borrowing country, indicative targets may precedes the QPC and as conducive economic environment is created the indicative target is appropriately structured as QPC. Structural benchmark is another critical element of conditionality prescribed to achieve the programme objective. Financial sector reforms, improving public finance are examples for structural benchmarks which are mutually agreed during programme implementation. (IM F 2017b, p 3)

\section{Indonesia}

The signs of financeable troubles became evident in Indonesia in the early nineties with average current account imbalance hovering around 3-4 per cent of GDP and the Non-Performing Assets ratio was 13 per cent. There were presences of many small under capitalised banks in the country.

During the first half of the decade the Debt-GDP ratio of the country was in the range of $57-68 \%$, while short term debt to foreign reserves were to the tune of 177 per cent. The ratio of foreign liabilities to assets of Banks was 424\% in 1996 (Corsetti et al 1999, Rieffel 2007). Sign of inflation and fall in trade surplus was visible in 1996.During the year, B ank of Indonesia (BI) made modest change interest rate and reserve requirement were raised from $2-5 \%$. In order to manage the capital flows the Rupiah trading band was raised from 2 per cent to 8 per cent in three stages. However, there was no dearth in capital flows appreciating the domestic currency.BI reduced the interest by 1 per cent during December 1996 to M ay 1997 to moderate capital flow. It is to be mentioned that Indonesian corporate were borrowing significantly from abroad.(Corsetti et al,1998). The pressure on currency became more visible in August 1997 and Indonesia confronted this by expanding intervention band. However with further sharp depreciation of currency Indonesia floated the currency in October 1997.0n5 November 1997, Indonesia has entered into a Standby A rrangement of USD 10 bn with the IM F.

\section{Table 2: Indonesia}

\begin{tabular}{|l|l|l|l|}
\hline $\begin{array}{l}\text { Economic Indicator } \\
\text { (Indonesia) }\end{array}$ & 1996 & 1997 & 1998 \\
\hline $\begin{array}{l}\text { Real GDP Growth } \\
\text { (\% of change) }\end{array}$ & 8.20 & 1.90 & $(-) 14.20$ \\
\hline $\begin{array}{l}\text { Current A ccount B alance } \\
\text { (\% of GDP) }\end{array}$ & $(-) 3.40$ & $(-) 0.90$ & 4.4 \\
\hline $\begin{array}{l}\text { External Debt } \\
\text { (\% of GDP) }\end{array}$ & 54.50 & 163.10 & 91 \\
\hline Source: https://www.imf.org/external/np/exr/ib/2000/062300.htm & \\
\hline
\end{tabular}

In November 1997, further to IMF assistance, Indonesian government put in place policy actions as per $\mathrm{M}$ emorandum of Financial and Economic Policies. The conditionality covers various policy initiatives to be undertaken in fiscal and monetary policy fronts as well as structural reforms. The salient features include sticking to sound fiscal policy aiming at budget surplus of 1 per cent. The monetary policy would target reining in inflation and arrest the sharp decline of exchange rate. The policy envisages maintain fiscal discipline by eliminating subsidies including that of fuel and electricity. In order to bolster the revenue, government would phase out VAT exemptions. The proposal include levying 5 per cent local sale tax of gasoline, increasing luxury tax and review of market value of land, building, plantation etc. The structural reforms include comprehensive assessment of health of banking system. Accordingly sixteen unhealthy banks were 
closed in November 1997. Structural reform aspect also proposed further foreign trade liberalization and exhorted for significant deregulation and privatisation drive. The removal of administrative price mechanism of cement was one of the measures implemented. The removal of import monopoly on certain food commodities enjoyed by government owned enterprise, BULOG was another decision (IM F, 1998).

After initial settling down, Rupiah again came under pressure during December 1997 and J anuary 1998. On November 1997, Indonesian closed sixteen insolvent banks in line with IM F Conditionality that had led to bigger uncertainties in domestic financial sector undermining the confidence of the depositors. The political and social unrest followed in the country had evened to the resignation of the President.
The period prior to the sub-prime crisis, Greece had been a big borrower from abroad. The joining of Euro by Greece in 2001, further reduced the risk perception of economy and more funds flew to Greece from within Europe. Greece had been reporting average 5 per cent of budget deficit as against Eurozone mandated 3 per cent. The current account deficit was at 9 per cent while the external debt in 2009 was nearing 100 per cent of GDP. In October 2009, the new government revised government budget deficit to 12.7 per cent which has led to rating agencies downgrading Greece (Belkin et.al,2011).The uncertainty regarding government data created panic among investors and this was reflected in the sovereign bond spread increasing to 400 basis pint vis-a-vis German bond. In M arch 2010 European U nion (EU) in concert with IMF has initiated financial assistance to Greece (Nelson, 2017).

\section{Greece}

Table 3: Greece

\begin{tabular}{|l|l|l|l|}
\hline Economic Indicators (Greece ) & 2009 & 2010 & 2011 \\
\hline $\begin{array}{l}\text { Real GDP Growth } \\
(\% \text { of change) }\end{array}$ & $(-) 2.0$ & $(-) 4.0$ & $(-) 2.60$ \\
\hline $\begin{array}{l}\text { Current A ccount Balance } \\
\text { (\% of GDP) }\end{array}$ & $(-) 11.20$ & $(-) 8.40$ & $(-) 7.10$ \\
\hline External Debt (\% of GDP) & 83.40 & 92.81 & 103.10 \\
\hline \multicolumn{2}{|l|}{ Source: https://www.imf.org/external/pubs/ft/scr/2010/cr10110.pdf } \\
\hline
\end{tabular}

The Greece was offered a very ambitious standby A rrangement of 110 bn Euro with EUR 30 bn from IM F and remaining from European A uthorities. The lending programme also warranted Greek authorities to embark upon an extra ordinary effort to comply with IM F adjustment offer. The fiscal conditionality include specific steps to bring down the Debt-GDP ratio from 2013 and government deficit to reach below 3 per cent by 2014.The expenditure measures included the elimination of allowance of high pensioners. The measures also included consolidation of local bodies and reduction in assistance to public enterprises. Revenue enhancing measures include increase in standard VAT Rate. Reduction in public sector wages and pension was critical element of structural reform list. Reforms in health sector were al so suggested. The list includes reframing of legal aspects regarding wage bargaining in private sector. In order to create conducive business environment it was suggested authorities would take steps to reduce red tapism and also initiate measure for liberalization and improve competition regulation. Better safety net mechanism for banking sector with suggestion to improve supervisory mechanism were also part of the Plan (IMF Country Report, 2010)

\section{Analysis of IMF Conditionality: Indonesia and Greece}

A study on IM F loan conditionality by Jesse Griffiths and Konstantino Todoulos (2014) undertaken for European Network on debt and development in 2014 has underscored the fact that there has been no reduction in actual conditionality. The Eurodad research undertaken during 2003-4 observed that the were average fourteen conditions then while its 19.5 as per latest estimate. The structural conditionality was fortyone for $\mathrm{G}$ reece. Further report also found that politically sensitive conditionality such as raising VAT, wage reduction, restructuring of public sector were still widely used. (Griffith and K onstantino,2014)

During the Asian crisis, IM F loans conditionality and policy prescription focused on fiscal discipline, bank restructuring and maintaining high interest rate to manage the capital flows and exchange rate.(Corset et al,1998).This approach has initiated a debate on whether the strategies or policy prescriptions of IMF has helped to alleviate the intensity of crisis or has placed these economies in more miseries. A nalyst argued that the higher interest policy followed by these economies during crisis time has further increased banking and corporate bankruptcy. The economist including Paul Krugman dismisses the loose policy argument. (K rugman,1999).

According to $M$ artin Feldstein, IMF is resorting to traditional fiscal policy measures such as higher taxes 
and low government spending, credit rationing by following high interest regime that were successful in Latin A merica. He observed that in these economies IM F has imposed the policy initiatives that can overhaul their economic and political system. He has cited the example of IM F involving to the extent of issues like gasoline price, curtailing business privileges of Indonesian President's family interests. According to Feldstein that these measures are advantageous for the economy but do not fall in the broader objective of Fund (Feldstein,1998).

It was argued that the fiscal discipline imposed by IM F has dampening effect on these economies. IM F has also revisited the strict fiscal conditionality and in case of Indonesia, the Fund had to revise the fiscal surplus estimate of 1 per cent to Budget Deficit below 8.50 per cent within a year of implementation of programme. . (Corsetti et al, 1998).

The closing of sixteen banks in Indonesia as part of IMF banking reforms has received wide criticism. According to Jeffery Sachs, the policy action of IM F had send misleading signals to the market and is observed as a "serious mistake". It may be mentioned that following the closing of banks, panicky depositors started moving their deposits to more safe government and foreign banks triggering liquidity issues. M ost of the banks were not able get fund in interbank market and there was unhealthy practice of trading excess liquidity and this has warranted central bank to intervene and infuse liquidity(Richardson,1998).

The Asian crisis has revealed an important aspect regarding how multilateral institutions must approach the crisis ridden economies. It brought out the fact the financial crisis has to be dealt differently from macro economic crisis. In the former case the institutions in distress has to be immediately supported and program must give priority to resurrect dwindling demand rather than insisting on stringent conditionality (Sterland, 2017).

There is an argument that that the IM F conditionality in A sia, has exceeded the purpose mentioned in Articles of Agreement and aspects such as deregulation, liberalization, public sector reforms do not come under the purview of Articles of Agreement. Hence conditionality were economically unviable and IMF action are possibly undermining the political and economic sovereignty of the respective country (Lee,2003).It may mention that the case study of Indonesia and Greece cited above also revealed the fact that though there has been substantial rationalisation of IMF conditionality during the period, intimidating nature of conditionality were glaringly visible both in Indonesia (1997) and Greece (2010) programme. Both in case of Indonesia and Greece there has been an undue pressure for budget balancing. The conditionality continue to insist on sensitive issues such as removing subsidiaries, increase in VAT and other taxes to shore up revenue, effort to reduce wages and pension, restructuring public sector, local government set up and all these are perfect recipes for exacerbating crisis and triggering political upheaval. This aspect was visible in both Indonesia and G reece.

\section{IMF GOVERNANCE REFORMS AND EMERGING ASIA}

IM F Governance Reform undertaken in 2010 and came to effect in J anuary 2016 is a significant development for emerging economies particularly of Asia. The doubling of quota enabled shift of $6 \%$ shares to dynamic emerging economies with Brazil, China, Russia and India becoming top 10 IM F shareholders. Two seats in board of European countries have also shifted to emerging economies. After the 14 quota review, IM F quota has been raised to SDR $476.8 \mathrm{bn}$ (2010) from SD R 238.4 bn.(2008).(T weedie et.al,2010).

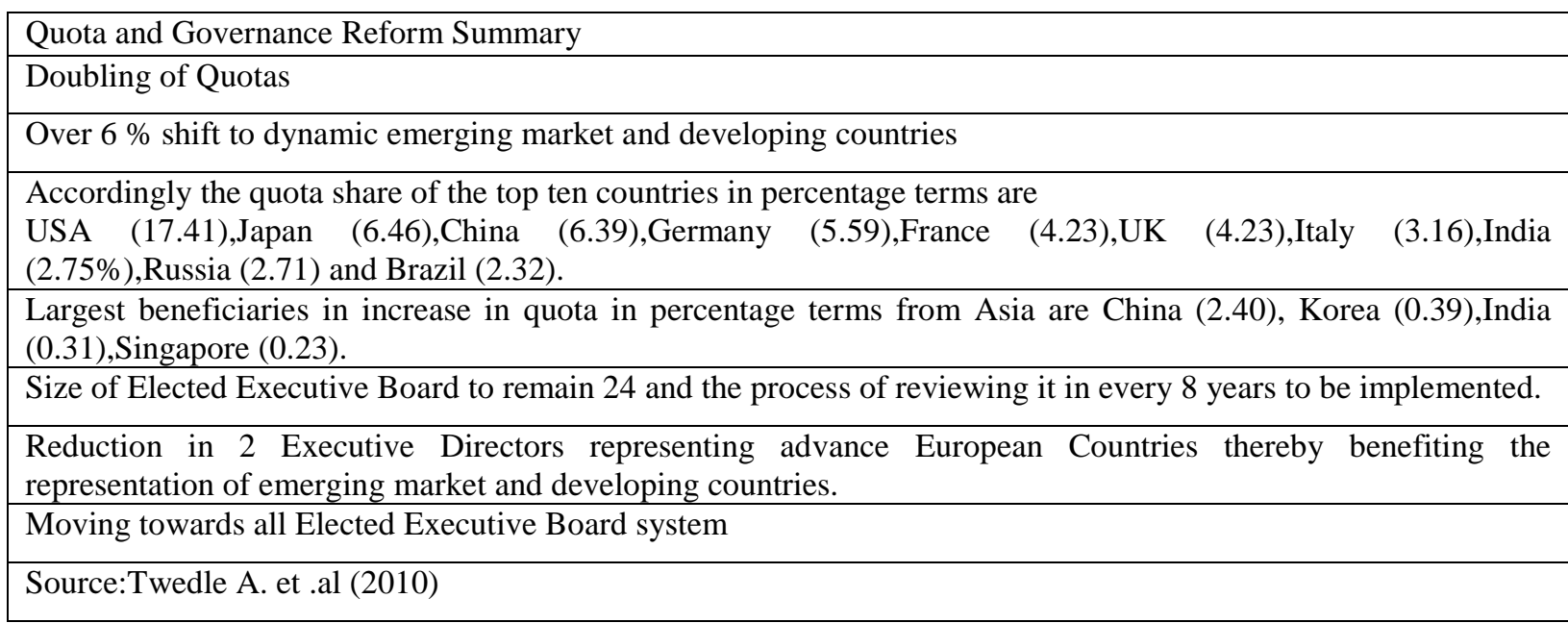


The entry of two Development Banks from Asia is another important development in global finance. A sia Infrastructure and Investment B ank (AIIB) led by China was established with capital base of USD 160 bn on 24 Oct 2014.The main focus of this developmental institution is infrastructure financing (S.R, 2014). The New Development Bank (B RICS Bank) was established by Brazil, China, India, Russia and South A frica with a composite capital base of US \$50 bn in July 2015 (Berensmann Kathrin,2016).B oth the intuitions are based in China and it essentially reflect the power shift from industrialised countries to emerging Asian countries (Wang, 2016) As per IMF estimates A sia would be emerging as largest economic zone replacing G 7 by $2030^{6}$. The region has resurrected from the devastating effect financial crisis of 1997 and now has become the most promising economic zone of the world.

\section{CONCLUSION}

IMF engagement with A sia dates back to its formative years, though focus had shifted more during the time of devastating 1997-98 Asian financial crisis. IMF was extensively associated the crisis ridden economies of Asia with a cumulative assistance to the tune of assistance USD $40 \mathrm{bn}$. IM F financial assistance during the Asian financial crisis had salvaged these beleaguered economies however the stringent conditionality had also invited wide criticism. The argument was that fiscal discipline and structural reforms initiated subsequent to financial assistance has many occasion has been inimical to feeble growth prospects the subject countries. It is also argued that conditionality and structural reforms has shaken the existing economic and political system occasionally undermining the economic sovereignty of borrowing countries. The crisis ridden economies of Indonesia (1997) and Greece (2010) are cases in point. IM F also as part of the learning from the past twenty years had also undertaken various step to streamline the loan conditionality giving more focus on social aspects and growth. However the case analysis of Indonesia and Greece reveal that though conditionality have been modified there has been no substantial reduction in number as well as approach towards issues sensitive to domestic economic and political environment. The budget balancing austerity measures such as reduction in wages, pension reforms, increasing tax, reviewing distribution of subsidies and public sector reforms as observed in Greece, still invite criticism and public discontent.

${ }^{6} \mathrm{~B}$ arkelyTom (2010) ,A sian E conomies will be bigger than $\mathrm{G} 7$ by 2030 ,says IM F ,The Australian Business Review ,, Retrieved from

http://www.theaustralian.com.au/business/economics/as ian-economy-will-be-bigger-than-g7-by-2030-saysimf/news-story/3ecdee2a602250925f3a0189ca85689f
The study also broadly underscore the fact that IMF conditionality require greater understanding of political and economic realities of borrowing countries and minimise the public discontent It also point towards the requirement to be more inclusive in the prevailing socio-economic conditions. The paper intends to serve as background study and offers further scope for indepth analysis of countrywise specific structural benchmark set by the IM F.

The last two decades had also witnessed the emergence of Asian countries such as China and India as significant players in global trade. Asian economies relatively unhurt by the global financial crisis undertook significant role in stabilising global economy by associating with G-20 platform, IMF and other multilateral institutions. Sensing the changing trends IM F also as part of its governance reforms in 2010 has provided greater role for emerging economies by increasing their quotas. As IMF is dominated by advanced Western industrialised economies, emerging economies led by China has also floated their own multilateral institutions. The establishment of $\mathrm{New}$ Development Bank (BRICS Bank) in 2014 and A sian Infrastructure Investment Bank (AlIB) in 2016 are reflection of increasing relevance of emerging east A sian economies in global financial sector. In the last two decades, Asian Emerging economies have made remarkable stride in terms economic growth and obviously emerged as main partners in IM F governing body as well as Fund's effort to maintain global financial stability.

\section{REFERENCES}

1) A ghevli Bijan B.(1999), "The Asian Crises: Causes and Remedies", Finance and Development, 36 (2).

2) Belkin Paul, et. Al. (2011),"Greece Debt Crisis: Overview, Policy Responses And Implications" , CRS Report for Congress R41167 , Congressional Research Service: Washington D.C ,Retrieved 13 December 2017, $U R L$ http://https://www.cfr.org/content/publications/ .../CRS\%20-\%20G reece\%20D ebt\%20C risis.p.

3) Berensmann Kathrin (2016), "M ultilateral Banks:New Players with Handicaps", $D+C$ Development and Co-operation:Frankfurt am Main 1 A pril,Retrieved 13 December 2017, URL https://www.dandc.eu/en/article/asianinfrastructure-investment-bank-aiib-and-newdevelopment-bank-ndb-are-changing

4) Claessens Stijn and M.Ayan Kose (2013), "Financial Crisis:Explanations,Types and Implications",IM F Working Paper WP/13/28, International M onetary Fund:W ashington D.C.Retrieved 13 December 2017, 
https://www.imf.org/external/pubs/ft/wp/2013/ wp1328.pdf

5) Corsetti, G. (1998), "Interpreting the Asian financial crisis:Open Issues in Theory and Policy", Asian D evelopment Review, 16(2), 1863. Retrieved 13 December 2017, URL: http://www.econis.eu/PPNSET?PPN =32 7773820

6) Corsetti G,Paolo Pesento and Nouriel Roubini (1998), "W hat caused the A sian currency and Financial crisis:A Macroeconomic Overview", NBER Working Paper 6833,National Bureau of E conomic Research:M assacheutus.

7) Dowling, M. (1997), "A sia's Economic Miracle: An Historical Perspective", The Australian Economic Review, 30(1), 113-123.

8) Enoch, Charles (2000), "Intervention in Banks During Banking Crises:The Experience of Indonesia",IM F Policy Discussion Paper PDP/00/2, International M onetary Fund:W ashington D.C.

9) Feldstein Martin(1998), "Refocusing the IM F",F oreign 33,M arch/A pril.

10) Fischer Stanley (1998), "The IMF and the A sian Crisis", Speech delivered on $20 \mathrm{M}$ arch at the Forum Fund Lecture at UCLA :LoS Angeles

11) Garnaut ,Ross and Ross H McLeod (2002), 'East A sia in Crisis:From Being a M iracle to Needing One,'Routledge:L ondon \& N ew Y ork.p22.

12) Griffith Jesse and Konstantino Todoulos(2014), "Conditionally Yours:An Analysis of the policy condition attached to IM F loans",European Network on Debt and Development(EURODAD):B russels. Retrieved $13 \quad$ December 2017 URL:http://eurodad.org/files/pdf/533bd19646b 20.pdf.

13) IM F (1998), "Indonesia-M emorandum of Economic and Financial Policies", International Monetary Fund: Washington D.C. Retrieved 13 December 2017 URL: https://www.imf.org/external/np/loi/011 598.htm

14) IMF (2009), "IM F at a Glance", International Monetary Fund Washington .D.C 4 A pril.Retrieved 13 D ecember 2017 URL:http://www.imf.org/A bout/Factsheets/IM F-at-a-Glance? pdf $=1$

15) IMF (2010),"Greece Request for Stand-by A rrangement",IMF Country Report No 10/11, International Monetary Fund:W ashington D.C May.Retrieved 13 December 2017
URL:https://www.imf.org/external/pubs/ft/scr/ 2010/cr10111.pdf

16) IM F (2017a), "Gold in the IM F", International $M$ onetary Fund Fact Sheet, International M onetary Fund: Washington D.C. Retrieved $13 \quad$ December 2017 URL: http://www.imf.org/A bout/Factsheets/Sh eets/2016/08/01/14/42/G old-in-theIM F ? pdf $=1$.

17) IM F 2017

b), "IM F Conditionality",International M onetary Fund Fact Sheet, International M onetary Fund: Washington D.C,23 October. Retrieved 13 December 2017 URL:https://www.imf.org/A bout/Factsheets/S heets/2016/08/02/21/28/I M FConditionality?pdf $=1$.

18) K rugman Paul (1999),"A nalytical Afterthoughts of Asian Crisis", Retrieved 13 December 2017 URL: http://web.mit.edu/krugman/www/M IN I CRIS.htm

19) Lee Catherine (2003), "To Thine ownself be True: IMF conditionality and Erosion of E conomic Sovereignty In The A sian Financial Crisis ",U niversity of Pennsylvanya J ournal of International Law ,24(4):875, Retrieved 13 December 2017 URL: http://scholarship.law.upenn.edu/jil/vol2 $4 /$ iss $4 / 2$

20) Nanto Dick K.(1998), "The 1997-98 Asian Financial Crisis",Congressional Research Service Report, 6 February.Retried from URL: https://fas.org/sgp/crs/row/crs-asia2.htm

21) Nelson Rebecca (2017), "The Greek Debt Crisis, Continuing Challenges",CRS Insight,Congressional Research Service 2 March IN 10658 Retrieved 13 December 2017 URL https://fas.org/sgp/crs/row/IN 10658.pdf

22) Richardson,M ichael(1998), " $Q \& A / J$ effrey Sachs:IM F Prescribes Wrong Medicine", The Newyork Times, NewY ork, Retrieved 13 December 2017 URL:http://www.nytimes.com/1998/01/15/bus iness/worldbusiness/q-a-jeffrey-sachs-imfprescribes-wrong-medicine.html

23) Rieffel ,Lex (2007), "Indonesia,Ten years After the Crisis",B Bookings Institution:B russels. Retrieved 13 December 2017URL:https://www.brookings.edu/opinions /indonesia-ten-years-after-the-crisis/

24) S.R (2014),"W hy China creating a N ew W orld Bank for Asia",The Economist 11 November.Retrieved 13 December 2017 
URL :https://www.economist.com/blogs/econo mist-explains/2014/11/economist-explains-6

25) Sterland Barry (2017), "The Asian Financial Crisis:20 Y ears on:Lessons Learnt and Remaining Challenges", Brookings Institution:W ashington D.C,2 July.Retrieved $13 \quad$ December 2017 URL:https://www.brookings.edu/opinions/theasian-financial-crisis-20-years-on-lessonslearnt-and-remaining-challenges/

26) Tweedie Andrew, Sean Hagan and Reza Moghadam (2010), "IM F Quota and Governance Reform-Elements of an A greement",International M onetary Fund:W ashington D.C Retrieved 13 December 2017

URL :https://www.imf.org/external/np/pp/eng/ 2010/103110.pdf

27) Wang Hongying (2016), "New Multilateral Development Bank:Opportunities and Challenges for Global Governance",Part of Discussion Paper Series on Global and Regional Governance of the Council on Foreign Relations. Retrieved 13 December 2017U RL: http://i.cfr.org/content/publications/ attachments/Discussion_Paper_Wang_M DBs_ OR.pdf 